\title{
EFFECT OF FULVIC ACID, SOME MICRO-ELEMENTS AND MICRO-ORGANISMS ON YIELD AND ITS COMPONENTS, CONTENT FRUITS OF MACRO- AND MICRO- ELEMENTS CONTENT OF ZAGHLOUL DATE PALM.
}

El-boray, M. S. S.* ; M. F . M. Mostafa* ; A. F. Abd El-wahab**and A. N. A. Elattar

* Pomology Department, Faculty of agriculture, Mansoura University

**Water, Soil and Environment Rsearch Institute, Cario

\begin{abstract}
The present work was carried out in newly reclaimed land at the Experimental Station of the Faculty of Agriculture (Kalabshow and Zayan), Mansoura University, Dakahlia Governorate, Egypt. to study the effect of fulvic acid, some micro elements and microorganisms on yield and its components, fruits content of macro- and microelement of Zaghloul date palm.

The obtained results indicated that fulvic acid applied at $83.33 \mathrm{ml} / \mathrm{palm}$ tree + microorganisms at $83.33 \mathrm{ml} /$ palm conjugation with micro elements at $(3.12 \mathrm{gm}$ from $\mathrm{FeSO}_{4} .7 \mathrm{H}_{2} \mathrm{O}+1.56 \mathrm{gm}$ from $\mathrm{ZnSO}_{4} .7 \mathrm{H}_{2} \mathrm{O}+1.56 \mathrm{gm}$ from $\mathrm{MnSO}_{4} . \mathrm{H}_{2} \mathrm{O}$ ) as soil application / palm ( $\left.T_{7}\right)$ gave significant increase yield/ palm ( 174.16 and $169.33 \mathrm{~kg}$ ), fruit weight $\left(33.2^{9}\right.$ and $\left.32.45 \mathrm{gm}\right)$ and flesh weight $(30.927$ and $30.070 \mathrm{gm})$, whereas the yield of $\mathrm{T}_{1}$ control $(96.16$ and $92.23 \mathrm{~kg} / \mathrm{palm})$, fruit weight $(20.34$ and $19.63 \mathrm{gm})$ and flesh weight (18.47 and $17.95 \mathrm{gm}$ ) in both seasons of the study, respectively.

All treatments of organic compounds extracts and microelements gave significant increase in the values of NPK and Fe, Zn and Mn in Date palm fruits as compared to control treatment in both seasons of the study .
\end{abstract}

\section{INTRODUCTION}

Date palm (Phoenix dactylifera L.) is one of the oldest fruit trees in the world. It is known as "tree of life" because of its resilience, its need for limited water inputs, its long term productivity and its multiple purpose qualities. In Egypt, dates are important traditional crops. According to FAO (2012), Egypt is considered as the first country of the top ten date producers $(1,130,000$ tones). Economically, Zaghloul date is the most important soft cultivar grown in Egypt. Organic fertilizers improve soil structure and enhance activities of useful soil organisms. Agricultural commodities resulted from organic cultivation are good for human health (Jayathilake et al., 2006). Fulvic acid is the most significant component of organic substances and highly beneficial to both plant and soil; it is important for increasing microbial activity, it is considered as a plant growth bio-stimulant, an effective soil enhancer; it promotes nutrient uptake as chelating agent and improves vegetative characteristics, nutritional status and leaf pigments (Eissa et al. 2007). There are a number of inoculants with possible practical application in crops where they can serve as useful components of integrated plant nutrient supply systems. Such inoculants may help in increasing crop productivity by increasing biological $\mathrm{N}$ fixation (BNE), availability or uptake of nutrients 
through solubilization or increasing absorption, stimulation of plant growth through hormonal action or antibiosis or by decomposition of organic residues (Wani, and Lee 1995). The present study was undertaken to investigate the effect of organic, biofertilizers and microelements ( $\mathrm{Fe}, \mathrm{Zn}$ and $\mathrm{Mn}$ ) on the yield, macro and micro elements content of Zaghloul date palm fruits.

\section{MATERIALS AND METHODS}

Effect of fulvic acid, some micro-elements ( $\mathrm{Fe}, \mathrm{Zn}$ and $\mathrm{Mn}$ ) and micro- organisms (Serratia $s p+$ Bacillus polymyxa + Pseudomonas fluorescens + Trichoderma viride + Trichoderma harzianum) on yield and its components, fruits content of macro and micro elements of date palm Zaghloul cv. The experiment carried out at the Experimental Station of the Faculty of Agriculture (Kalabshow and Zayan), Mansoura University, Dakahlia Governorate, Egypt. Female palms with similar vigor, height, pollen source and age (10 years old) were selected and subjected to the normal cultural practices applied for date palms and planted at $7 \times 7 \mathrm{~m}$ under furrow irrigation system. seven soil application treatments were arranged in a completely randomized design with three replicates ( 1 replicate $=2$ palms) per treatment (i.e. $7 \times 3 \times 2=42$ palm).

The treatments were as follows:

T1: Control (treated with water only).

T2: Fulvic acid only at $83.33 \mathrm{ml} \mathrm{Liters/palm.}$

T3: Microelements only at $\left(3.12 \mathrm{gm}\right.$ from $\mathrm{FeSO}_{4} .7 \mathrm{H}_{2} \mathrm{O}+1.56 \mathrm{gm}$ from $\mathrm{ZnSO} 4.7 \mathrm{H}_{2} \mathrm{O}+1.56 \mathrm{gm}$ from MnSo $\left.4 . \mathrm{H}_{2} \mathrm{O}\right) / \mathrm{palm}$.

T4: Micro-organisms only at $83.33 \mathrm{ml}$ Liters $/$ palm.
T5: $\mathrm{T} 2+\mathrm{T} 3$
T6: T2 + T4
$\mathrm{T} 7: \mathrm{T} 2+\mathrm{T} 3+\mathrm{T} 4$

These treatments added in three dates:

1- After full bloom and the beginning of set stage of date fruit at 23/4/2010 and 29/4/2011 seasons.

2- At Kamri stage of date fruit at $29 / 6 / 2010$ and $5 / 7 / 2011$ seasons.

3 - At the beginning of date fruit color at $6 / 8 / 2010$ and $11 / 8 / 2011$ seasons.

These treatments were applied in circle holes around each palm trees with $50 \mathrm{~cm}$ depth and the distance from the palm trunk is $70 \mathrm{~cm}$.

Soil samples were taken to determine the properties of experimental soil at three depths from soil surface, 0 to $30 \mathrm{~cm}, 30$ to $60 \mathrm{~cm}$ and 60 to $90 \mathrm{~cm}$. Such samples were completely mixed and subjected to mechanical and chemical analysis to measure properties of soil as in Table 1.

Table (1):Mechanical and chemical analysis to measure certain properties of soil

\begin{tabular}{|c|c|c|c|c|c|c|c|c|c|c|c|c|}
\hline \multirow{2}{*}{ Depth } & \multicolumn{4}{|c|}{ Mechanical analysis } & \multicolumn{5}{|c|}{ Chemical analysis } & \multicolumn{3}{|c|}{$\begin{array}{c}\text { Available } \\
\text { (ppm) }\end{array}$} \\
\hline & $\begin{array}{c}\text { Sand } \\
\%\end{array}$ & $\%$ & $\begin{array}{c}\text { Clay } \\
\%\end{array}$ & $\begin{array}{c}\text { Texture } \\
\%\end{array}$ & $\begin{array}{l}\text { E.C. } \\
\text { ds/m }\end{array}$ & $\mathrm{H}$ & $\begin{array}{l}\text { Sp } \\
\%\end{array}$ & $\mathrm{CaCO}_{3} \%$ & $\begin{array}{l}\text { O.M. } \\
(\%)\end{array}$ & $\mathbf{N}$ & $P$ & K \\
\hline $0-30$ & 69.31 & 20.21 & 10.48 & \multirow{3}{*}{$\begin{array}{c}\text { Sandy } \\
\text { loamy } \\
\text { soil }\end{array}$} & 1.36 & 7.92 & 42 & 0.92 & 0.88 & 31.9 & 4.2 & 248 \\
\hline $30-60$ & 66.96 & 21.35 & 11.69 & & 1.12 & 8.01 & 45 & 3.25 & 0.63 & 28.7 & 3.7 & 225 \\
\hline $60-90$ & 65.11 & 22.94 & 11.95 & & 1.03 & 8.08 & 49 & 2.07 & 0.57 & 27.2 & 3.2 & 212 \\
\hline
\end{tabular}


Preparation of Fulvic acid:

Compost prepared from Rice straw, Farmyard manure, Rock phosphate, Bentonite and Urea were digested with $0.5 \mathrm{~N} \mathrm{KOH}$ for $48 \mathrm{~h}$ at room temperature in the ratio of $1 / 10(\mathrm{~W} \backslash \mathrm{V})$. Separation of the solute form the undigested residues were then carried out by filtration by 100 Mesh screen. The supernatant was acidified at $\mathrm{pH} 2$ with concentrated $\mathrm{H}_{2} \mathrm{SO}_{4}$ and left settling for $24 \mathrm{~h}$ in the dark in order to allow humic acid flocculation. Fulvic acid was collected by filtration. (Vallini et al., 1990).

Table (2): analysis of fulvic acid

\begin{tabular}{|l|c|}
\hline \multicolumn{1}{|c|}{ Trait } & Value \\
\hline PH & 2.8 \\
\hline E.C (ds/m) & 8.68 \\
\hline Organic-C (\%) & 2.81 \\
\hline Available-N (PPM) & 210 \\
\hline Available -P(PPM) & 7.4 \\
\hline Total-K(\%) & 2.26 \\
\hline
\end{tabular}

\section{Preparation of Micro organisms inoculants :}

Serratia sp, grown on pepton - glycerol media (Grimont and Grimont, 1984), Pseudomonas fluorescens grown on king's media (Alef, 1995), Bacillus polymyxa grown on nutrient broth media (Dowson, 1957) and Trichoderma species grown on Potato dextrose media (ATTC,1992)were incubated for $2-3$ days at $28{ }^{\circ} \mathrm{C}$ to maintain populations of $3 \times 10^{8}$ colony forming unit $\mathrm{ml}^{-1}$ (CFU $\left.\backslash \mathrm{ml}\right)$. All microbial strains were kindly provided from Dept. of Microbiology, Soils, Water and Environment Research Institute (SWERI), Agriculture Research Center (ARC).

The following measurements were carried out:

1- Yield /palm (Kg/palm) and its components: At the harvesting, the yield counted as accumulation from six times of harvest, where each harvest was weighted. The simple of Date palm fruits (100 fruits) were taken to determine its components.

2- Macro elements content in date palm fruits at harvest: The middle harvest (third) during the mid of September in both seasons, where the Date palms were harvested for six times, the simple of Date palm fruits (10 fruits) were taken and dried at $70 \mathrm{c}^{\circ}$ to determine the macro and micro elements as follow: yield of tested studied palms was recorded in $\mathrm{Kg}$ / palm.

2.1 Total nitrogen \%: Determined using micro-kjeldahl procedure according to the method described by Pregle (1945).

3.2 Phosphorus \%: it was measured as described by Jackson (1967).

4.3 Potassium \%: it was measured according to Black (1965).

5. Micro-elements content in date palm fruits at harvest: Iron, Zinc and Manganese elements were determined using Atomic-absorption (Analyst 200, Perkin Elmer, Inc., MA, USA), as described by Chapman and Pratt (1982). 
El-boray, M. S. S. et al.

The data of experiment was statistical analysis of variance according to Snedecor and Cochran (1980) and New LSD at $5 \%$ level as mentioned by Gomez and Gomez (1984).

\section{RESULTS AND DISCUSSION}

Data in Table (3) illustrate effect of some organic compounds extract and microelements as soil application on yield and its components of Date palm trees during 2010 and 2011 seasons. All tested treatments gave significant increase on yield / palm, fruit weight and flesh in both seasons of the study compared with control treatment (treated with water only)

Application of fulvic acid at $83.33 \mathrm{ml} /$ palm tree + treated palm tree with microorganisms at $83.33 \mathrm{ml} /$ palm conjugation with micro elements at $\left(3.12 \mathrm{gm}\right.$ from $\mathrm{FeSO}_{4} .7 \mathrm{H}_{2} \mathrm{O}+1.56 \mathrm{gm}$ from $\mathrm{ZnSO}_{4} .7 \mathrm{H}_{2} \mathrm{O}+1.56 \mathrm{gm}$ from MnSo4. $\left.\mathrm{H}_{2} \mathrm{O}\right)$ as soil application / palm/ $\left(\mathrm{T}_{7}\right)$ gave significant increase yield/ palm ( 174.16 and $169.33 \mathrm{~kg}$ ), fruit weight (33.29 and $32.45 \mathrm{gm})$ and flesh weight (30.93and $30.07 \mathrm{gm}$ ) in both seasons (2010-2011) of the study, respectively. While $\left(T_{6}\right)$ application of fulvic acid at $83.33 \mathrm{ml} / \mathrm{palm}+$ treated palm tree with microorganisms at $83.33 \mathrm{ml} /$ palm tree came in the second rank on yield (161.50 and $156.05 \mathrm{~kg} / \mathrm{palm})$, fruit weight (28.39and $30.75 \mathrm{gm}$ ) and flesh weight (26.15 and $28.48 \mathrm{gm}$ ) in 2010-and 2011 seasons, respectively. On the contrary, the yield from $T_{1}$ control recorded in this respect $(96.16$ and $92.23 \mathrm{~kg} / \mathrm{palm})$, fruit weight (20.34and $19.63 \mathrm{gm})$ and flesh weight (18.47and $17.95 \mathrm{gm}$ ) in both seasons of the study, respectively. All other treatments gave value in between the previous treatments.

Table (3): Effect of organic substance, micro-elements and microorganisms on yield traits during 2010 and 2011 seasons

\begin{tabular}{|l|c|c|c|}
\hline \multirow{2}{*}{ Treatments } & \multicolumn{3}{|c|}{ Yield and its components } \\
& $\begin{array}{c}\text { Yield / palm } \\
\text { (kg/palm) }\end{array}$ & $\begin{array}{c}\text { Fruit weight } \\
\text { (g) }\end{array}$ & $\begin{array}{c}\text { Flesh weight } \\
\text { (g) }\end{array}$ \\
\cline { 2 - 4 } & \multicolumn{3}{|c|}{$\mathbf{2 0 1 0 \text { season }}$} \\
\hline T1 & 96.16 & 20.34 & 18.47 \\
\hline T2 & 105.66 & 23.92 & 21.92 \\
\hline T3 & 101.55 & 21.59 & 19.63 \\
\hline T4 & 117.39 & 25.93 & 23.84 \\
\hline T5 & 132.94 & 26.37 & 24.20 \\
\hline T6 & 161.50 & 28.39 & 26.15 \\
\hline T7 & 174.16 & 33.29 & 30.93 \\
\hline New LSD at 0.05 level & $\mathbf{6 . 5 7}$ & $\mathbf{0 . 5 6}$ & $\mathbf{0 . 5 8}$ \\
\hline T1 & 92.33 & 19.63 & 17.95 \\
\hline T2 & 101.00 & 22.04 & 19.80 \\
\hline T3 & 97.67 & 20.48 & 18.45 \\
\hline T4 & 112.83 & 23.05 & 20.95 \\
\hline T5 & 129.83 & 29.34 & 27.19 \\
\hline T6 & 156.05 & 30.75 & 28.48 \\
\hline T7 & 169.33 & 32.45 & 30.07 \\
\hline New LSD at 0.05 level & $\mathbf{4 . 9 7 6}$ & $\mathbf{1 . 1 0}$ & $\mathbf{1 . 0 3 4}$ \\
\hline
\end{tabular}


Improving yield of date palm can be achieved through better cultural practices such as soil application of organic compounds extracts, which contained some plant nutrition, some of these nutrition are known as micronutrients i.e., $\mathrm{Zn}, \mathrm{Fe}$ and $\mathrm{Mn}$ or amino acids and humic acid that are essential for producing healthy date trees as well as increasing the productivity of trees (Tan 2003). In addition, fulvic acid is highly beneficial to both plant and soil; it is important for increasing microbial activity, it is considered as a plant growth bio-stimulant, an effective soil enhancer; it promotes nutrient uptake as chelating agent and improves vegetative characteristics, nutritional status, leaf pigments and increasing fruit yield of date palm (Eissa et al. 2007).

These results are confirmed with those of Kaloosh (1993) studied on fertilization of Date palm trees by compost and reported that increasing the level of the compost from 0 to $25 \mathrm{~kg} /$ tree increased the yield from 16.7 to $35.4 \mathrm{~kg} / \mathrm{tree}$. Also found that the application of 20 to $25 \mathrm{~kg}$ of tested compost/tree doubled the yield of the Date palm trees.

Mostafa et al. (2009) carried out an experiment on 15-year-old Thompson seedless grapevines (Vitis vinifera, L.) grown in clay soil in Belkas district, Dakahlia Governorate, Egypt in 2003 and 2004 seasons. They studied the effect of some natural organic nutrients including compost tea and chicken manure extracts at different concentration (1:10, 1:20 and 1:30) on yield/vine. They found that the highest yield values relatively were obtained from vines that sprayed with mixed from compost tea and chicken manure extract at rate of 1:10 x 1:10 w/v. Such yield was 19.82 and $20.41 \mathrm{Kg} / \mathrm{vine}$ in the 2003 and 2004 seasons, respectively.

Marzouk and Kassem (2011) on Zaghloul palm cultivar, revealed that fruit weight, flesh weight, length, diameter and dry weight were increased by the application of organic manures either alone or in combination with mineral NPK as compared to the mineral N..

\section{Fruits content of macro element}

\section{1-Nitrogen percentage}

Data in Table (4) showed that effect of organic compound extracts and microelements on fruit content of nitrogen during 2010 and 2011 seasons. All treatments of organic compounds extracts and microelements gave significant increase in the values of nitrogen content of fruits in both seasons of the study compared with control, whereas $\mathrm{T}_{7}$ (treated of date palm with $83.33 \mathrm{ml} /$ palm fulvic acid plus the mixture of $3.12 \mathrm{gm} \mathrm{FeSO}_{4} .7 \mathrm{H}_{2} \mathrm{O}+1.56$ gm of $\mathrm{ZnSO}_{4} .7 \mathrm{H}_{2} \mathrm{O}+1.56 \mathrm{gm} \mathrm{MnSO}_{4} . \mathrm{H}_{2} \mathrm{O}$ and $83.33 \mathrm{ml} / \mathrm{palm}$ microorganisms as soil application) recorded the highest values (5.177 and 5.573\%, in 2010 and 2011 seasons, respectively) without significant differences between ( $\left.T_{5}\right)$ application of $83.33 \mathrm{ml} / \mathrm{palm}$ fulvic acid as soil application + mixture of 3.12 gm FeSO $4.7 \mathrm{H}_{2} \mathrm{O}+1.56 \mathrm{gm}$ of $\mathrm{ZnSO}_{4} .7 \mathrm{H}_{2} \mathrm{O}+1.56 \mathrm{gm} \mathrm{MnSO}_{4} . \mathrm{H}_{2} \mathrm{O} /$ palm as soil application ( 5.097 and $5.487 \%$ in the $1^{\text {st }}$ and $2^{\text {nd }}$ seasons, respectively. While the lowest values in this respect was obtained with control treatment (treated date palm with water only) and recorded 4.190 and $4.510 \%$ in the $1^{\text {st }}$ and $2^{\text {nd }}$ seasons, respectively. 


\section{Phosphorus percentage}

Data given in Table (4) indicated that P\% significantly increased in fruits by application of organic compound extracts and some microelements in 2010 and 2011 seasons. All treatments of organic compounds extracts and microelements as soil application gave

significant increase in fruit phosphorus content values in the two seasons of the study compared with control treatment, whereas $\mathrm{T}_{7}$ gave the highest values of fruit phosphorus content $\left(0.765\right.$ and $0.704 \%$ in $1^{\text {st }}$ and $2^{\text {nd }}$ seasons, respectively), followed by $T_{5}$ treated of palm with $83.33 \mathrm{ml} / \mathrm{palm}$ fulvic acid as soil application + mixture of $3.12 \mathrm{gm} \mathrm{FeSO} 4.7 \mathrm{H}_{2} \mathrm{O}+1.56 \mathrm{gm}$ of $\mathrm{ZnSO}_{4} .7 \mathrm{H}_{2} \mathrm{O}+1.56 \mathrm{gm} \mathrm{MnSO} 4 . \mathrm{H}_{2} \mathrm{O} /$ palm as soil application ( 0.737 and $0.678 \%$ in the $1^{\text {st }}$ and $2^{\text {nd }}$ seasons, respectively. On the contrary, control treatment gave the lowest values of fruit phosphorus content compared with other treatments in the two seasons of the study $(0.620$ and $0.571 \%$ in the $1^{\text {st }}$ and $2^{\text {nd }}$ seasons, respectively).

\section{Potassium percentage}

Data tabulated in Table (4) cleared the effect of organic, microelements and microorganism as soil application on fruit potassium content of date palm during 2010 and 2011 seasons. Treated of date palm with organic compound extracts and some microelements had significant effect on potassium content in fruits in both season.

Table (4): Effect of organic, microelements and microorganisms on N,P and $\mathrm{K}$ contents in fruits during 2010 and 2011 seasons

\begin{tabular}{|c|c|c|c|}
\hline \multirow{3}{*}{ Treatments } & \multicolumn{3}{|c|}{ Microelements content (\%) } \\
\hline & $\mathbf{N}$ & $\mathbf{P}$ & $\mathbf{K}$ \\
\hline & \multicolumn{3}{|c|}{2010 season } \\
\hline T1 & 4.190 & 0.620 & 5.097 \\
\hline T2 & 4.440 & 0.653 & 5.390 \\
\hline T3 & 4.700 & 0.685 & 5.670 \\
\hline T4 & 4.427 & 0.657 & 5.457 \\
\hline T5 & 5.097 & 0.737 & 6.120 \\
\hline T6 & 4.823 & 0.711 & 5.820 \\
\hline T7 & 5.177 & 0.765 & 6.283 \\
\hline \multirow[t]{2}{*}{ New LSD at 0.05 level } & 0.100 & 0.013 & 0.093 \\
\hline & \multicolumn{3}{|c|}{2011 season } \\
\hline T1 & 4.510 & 0.571 & 4.743 \\
\hline T2 & 4.777 & 0.601 & 5.013 \\
\hline T3 & 5.060 & 0.631 & 5.273 \\
\hline T4 & 4.767 & 0.605 & 5.073 \\
\hline T5 & 5.487 & 0.678 & 5.690 \\
\hline T6 & 5.193 & 0.655 & 5.410 \\
\hline T7 & 5.573 & 0.704 & 5.847 \\
\hline New LSD at 0.05 level & 0.111 & 0.012 & 0.083 \\
\hline
\end{tabular}

All treatments recorded significant increase in fruit content of potassium in both seasons of the study as compared with control treatment, whereas $\mathrm{T}_{7}$ treatment(treated of date palm with $83.33 \mathrm{ml} /$ palm fulvic acid plus the mixture of $3.12 \mathrm{gm} \mathrm{FeSO}_{4} .7 \mathrm{H}_{2} \mathrm{O}+1.56 \mathrm{gm}$ of $\mathrm{ZnSO}_{4} .7 \mathrm{H}_{2} \mathrm{O}+1.56$ gm $\mathrm{MnSO}_{4} . \mathrm{H}_{2} \mathrm{O}$ and $83.33 \mathrm{ml} /$ palm microorganisms as soil application) gave the highest increase of potassium fruit content $(6.283$ and $5.847 \%$ in 
two seasons, respectively) comparing with the rest treatments. $T_{5}$ came in the second rank (6.120 and $5.690 \%$ in both seasons 2010-2011, respectively). On the other hand, the control treatment gave the lowest values of potassium compared to other treatments in two seasons of the study (5.097 and 4.743 $\%$ in 2010 and 2011 seasons, respectively).

The important role of organic compounds extracts in soil may exhibit through enhancement of the nutrient elements availability by reducing soil $\mathrm{pH}$, increasing the exchangeable capacity and reducing their losses by leaching as well as the ability of organic chelating agents to protect the nutrient elements against the conversion to unavailable forms.

These results are in agreement with there reported by Ahmed et al. (1997) studied the effect of amending a foliar applied spray containing (N, P, $\mathrm{K}, \mathrm{Mg}, \mathrm{Zn}, \mathrm{Fe}, \mathrm{Mn}, \mathrm{Cu}$ and $\mathrm{B})$ with glycerol $(0.05 \%)$ or active dry yeast $(0.1 \%)$ on its efficiency were investigated on grapes cv. Red Roumy in Egypt. They indicated that all the treatments improved nutritional status of vines.

\section{Fruits micro-elements contents}

Date in Table (5) show the effect of organic compound extracts and some microelements on $\mathrm{Fe}, \mathrm{Zn}$ and $\mathrm{Mn}$ concentration in fruits at harvest time during 2010 and 2011 seasons. Treated of date palm trees with organic extracts such as fulvic acid, microorganisms and some microelements (Fe, $\mathrm{Zn}$ and $\mathrm{Mn}$ ) as soil application had significantly increased $\mathrm{Fe}, \mathrm{Zn}$ and $\mathrm{Mn}$ concentration in fruits as compared to control treatment in both seasons.

Table (5): Effect of organic, micro-elements and micro-organisms on fruits contents of $\mathrm{Fe}, \mathrm{Zn}$ and Mn during 2010 and 2011 seasons.

\begin{tabular}{|l|c|c|c|}
\hline \multirow{2}{*}{ Treatments } & \multicolumn{3}{|c|}{ Microelements content (ppm) } \\
\cline { 2 - 4 } & Fe & Zn & Mn \\
\cline { 2 - 4 } & \multicolumn{3}{|c|}{$\mathbf{2 0 1 0 \text { season }}$} \\
\hline T1 & 18.98 & 8.59 & 10.48 \\
\hline T2 & 20.03 & 9.07 & 10.58 \\
\hline T3 & 21.24 & 9.58 & 10.11 \\
\hline T4 & 20.24 & 9.17 & 11.48 \\
\hline T5 & 23.15 & 10.33 & 10.85 \\
\hline T6 & 21.73 & 9.84 & 11.73 \\
\hline T7 & 23.41 & 10.64 & $\mathbf{0 . 1 0}$ \\
\hline New LSD at 0.05 level & $\mathbf{0 . 1 3}$ & $\mathbf{0 . 1 4 1}$ & 9.79 \\
\hline & & $\mathbf{2 0 1 1}$ season & 10.30 \\
\hline T1 & 21.32 & 8.85 & 10.93 \\
\hline T2 & 22.50 & 9.34 & 10.45 \\
\hline T3 & 23.86 & 9.86 & 11.87 \\
\hline T4 & 22.74 & 9.45 & 11.21 \\
\hline T5 & 26.01 & 10.64 & 12.12 \\
\hline T6 & 24.41 & 10.14 & $\mathbf{0 . 1 1}$ \\
\hline T7 & 26.30 & 10.96 & $\mathbf{0 . 1 4 1}$ \\
\hline New LSD at 0.05 level & $\mathbf{0 . 1 4}$ & & \\
\hline
\end{tabular}

In this regard application of $\mathrm{T}_{7}$ gave the higher values ( 23.42 and $26.30 \mathrm{ppm}$ ) for $\mathrm{Fe},(10.64$ and $10.96 \mathrm{ppm}$ ) for $\mathrm{Zn}$ ( 11.73 and $12.12 \mathrm{ppm}$ ) for $\mathrm{Mn}$ in the 2010 and 2011 seasons, respectively, followed by T5 (23.153 and $26.007 \mathrm{ppm})$ for $\mathrm{Fe}$, (10.330 and $10.640 \mathrm{ppm})$ for $\mathrm{Zn}(11.483$ and 11.867 ppm) for $\mathrm{Mn}$ in the 2010 and 2011 seasons, respectively. While T1 control 
treatment recorded the lowest values (18.980 and $21.320 \mathrm{ppm})$ for $\mathrm{Fe}$, (8.587 and 8.845ppm) for Zn ( 9.477 and 9.793 ppm ) for $\mathrm{Mn}$ in the 2010 and 2011 seasons, respectively.

These results are in harmony with these reported by Abd El-Naby and Gomaa (2000) working on Maghrabi banana plants. They found that the adding of organic combined with inorganic fertilizers produced fruits with a higher content of iron.

\section{REFERENCES}

Abd El-Naby, S.K.M. and A.M. Gomaa 2000 Growth, nutritional status, yield and fruit quality of Maghrabi banana as affected by some organic manures and biofertilizer". Minufiya J. Agric. Res. 25 (4): 1113-1129.

Ahmed, F. F., M. A. Ragab, A. A. Ahmed and A. E. M. Monsoor 1997. Improving the efficiency of spraying different nutrients for red roamy grapevines (VVL) by using glycerol and active dry yeast. Egy. J. Horti, 24(1) : 91- 108.

Alef, K. 1995.Methods In Applied Soil Microbiology And Biochemistry. $2^{\text {nd }} \mathrm{Ed}$ ., PP. 360-361. Academic Press Ltd., USA.

ATTC 1992. Catalogue Of Bacteria and Bacteriophages, $18^{\text {th }}$ ed., PP 428.

Black, C.A. 1965. Methods of Soil Analysis Part-II. American Soc. of Agronomy Inc., Publisher Madison Wisconsin, USA., 1372-1376.

Chapman, H.D. and P.F. Pratt, 1982. Methods of Plant Analysis, I. Methods of Anaylsis for Soil, Plant and Water. Chapman Publishers, Riverside, California, USA

Dowson, G. J. 1957. Plant Disease due Bacteria . Seconded, Cambridge, The University Press, London, PP. 231.

Eissa F. M., M.A. Faith and S.A. El-Shall 2007. The Role of humic acid and rootstock in enhancing salt tolerance of "Le-Conte" pear seedlings. J. Agric. Sci. Mansoura Univ., 32(5): 3651-3666.

FAO STAT Agricultural Data. http://faostat.fao.org/ (last accessed 1 June 2012).

Gomez, K.N. and A.A. Gomez 1984. Statistical Procedures for Agricultural Research. John Wiley and sons, New York, $2^{\text {nd }}$ ed., 68p.

Grimont, P.A. D. and F.Grimont 1984. Bergey' s Manual of Systematic Bacteriology. Williams \& Wilkins, Kneg,N. R. (eds),. Vol. 1, PP.477483, Baltimore/ London.

lqbal, M., A.Ghafoor and S. Rahman 2004. Effect of pollination times on fruit characteristics and yield of date palm cv. Dhakki. Int. J. Agric. Biol. 6, 96-99.

Jackson, M. L. 1967. Soil Chemical Analysis Advanced Course. Puble., Dept. of Soils, Univ. of Wise. Madison 6, Wishensin, U.S.A.

Jayathilake, P.K.S., I.P. Reddy, D. Srihari and K. R. Reddy 2006. Productivity and soil fertility status as influenced integrated use of $\mathrm{N}$ fixing Biofertilizers, organic manures and inorganic fertilizers in onion. $J$ Agric. Sci, 2(1): 46-58.

Kaloosh, A.A. 1993. Characteristics and use of organic fertilizers in Dubai, U.A.E. J. Agric. Sci., Mansoura Univ. 18 (5): 1562-1565. 
Marzouk H.A. and H.A. Kassem 2011. Improving fruit quality, nutritional value and yield of Zaghloul dates by the application of organic and/or mineral fertilizers. Scientia Hort, 127 : 249-254.

Mostafa, M. F., M. S. EL-Boray and Samah Y. Abd-Elhamed 2009. Successful application of natural organic nutrients to produce safety fruits from Thompson seedless grapevines. J. Agric. Sci. Mansoura Univ., 34 (7): 8139-8149.

Pregl, E. 1945. Quantitative Organic Micro-analysis. 4th Ed. J. Chudrial, London.

Snedecor, G.W. and W.G. Cochran. 1980. Statistical Methods. $7^{\text {th }}$ ed., lowa State Univ., Press, Ames., lowa, U.S.A.

Tan, K.H., 2003. Humic matter in soil and environment, principles and controversies. Marcel Dekker, Inc., Madison, New York, pp: 408.

Vallini, G., A. Pera, G. Sorace, C. Cecchi and P. Manetti 1990. Green composting. Bio Cycle 31(6): 33-35.

Wani, S.P. and K.K. Lee, 1995. Microorganisms as biological inputs for sustainable agriculture. In organic agriculture, theory and practices (ed.) P.K. Thampan, Peekay Tree Crops Development Foundation, Gandhi Nagar-Cochin 682-220, pp: 36-76

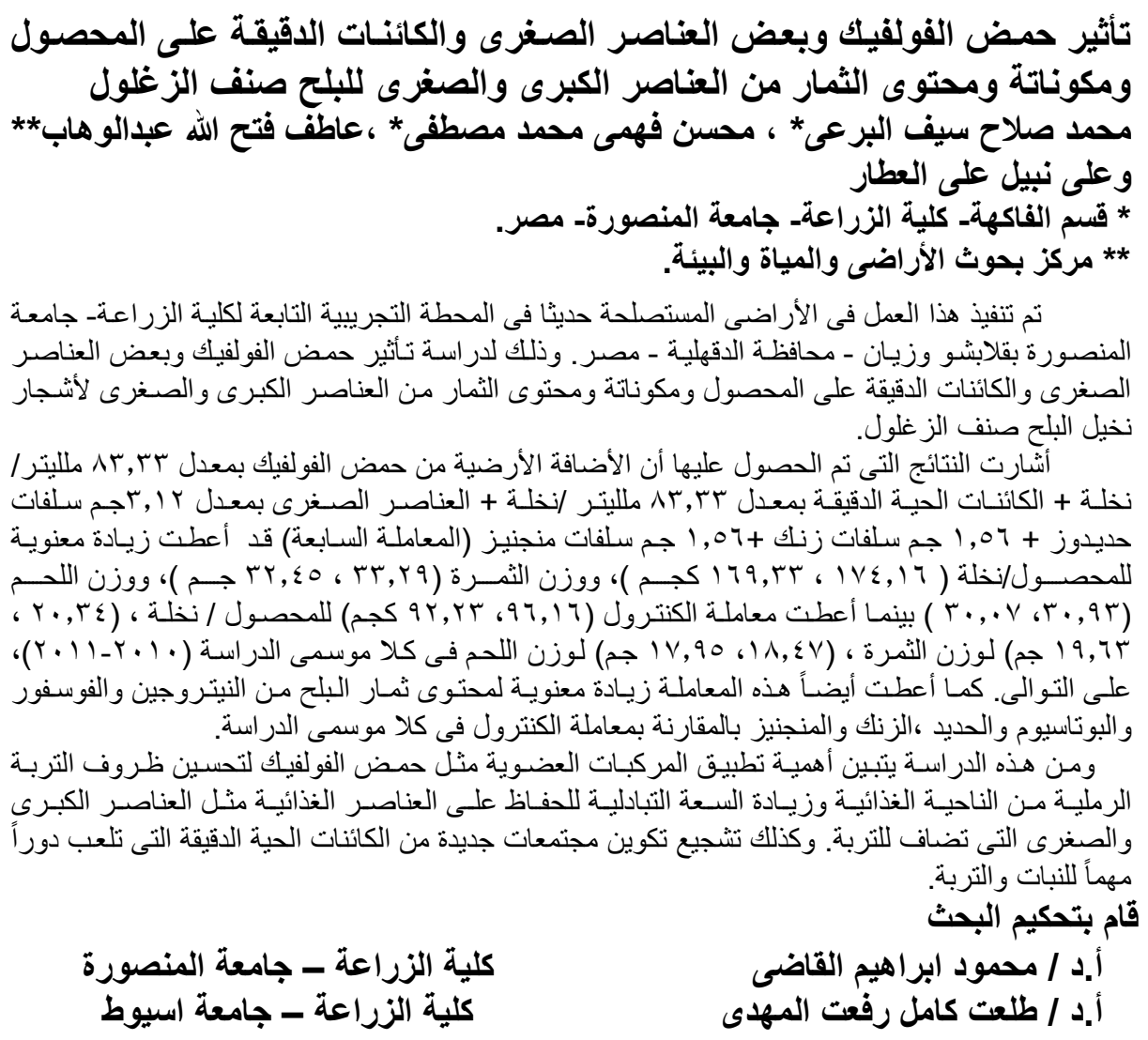

